\title{
Literasi Kesehatan Mental Orang Dewasa dan Penggunaan Pelayanan Kesehatan Mental
}

\section{Mental Health Literacy in Adults and Mental Health Service Use}

\author{
Trisni Handayani ${ }^{1, *}$, Dian Ayubi ${ }^{1}$, Dien Anshari ${ }^{1}$
}

${ }^{1}$ Departemen Pendidikan Kesehatan dan Ilmu Perilaku, Fakultas Kesehatan Masyarakat, Universitas Indonesia, Depok 16424.

*Korespondensi penulis: fh120807@gmail.com

\begin{tabular}{ll}
\hline Diterima (Recieved) & $: 14$ Mei 2020 \\
Direvisi (Revised) & $: 28$ Mei 2020 \\
Diterima untuk diterbitkan (Accepted) & $: 27$ Juni 2020
\end{tabular}

\begin{abstract}
ABSTRAK
Latar belakang. Prevalensi penduduk Indonesia yang menderita gangguan mental emosional mengalami peningkatan, dimana prevalensi sebesar 6\% pada tahun 2013 meningkat menjadi 9,8\% pada tahun 2018. Pelayanan kesehatan jiwa bagi setiap orang dengan masalah kejiwaan (ODMK) belum diwujudkan secara optimal di wilayah Kecamatan Bogor Timur. Masih sedikit ODMK yang memanfaatkan pelayanan kesehatan jiwa
\end{abstract}

Tujuan. Penelitian ini bertujuan untuk mengetahui hubungan literasi kesehatan mental dengan pemanfaatan pelayanan kesehatan jiwa.

Metode. Penelitian ini menggunakan desain cross-sectional dengan pendekatan kuantitatif. Responden adalah orang dengan masalah kejiwaan yang bertempat tinggal di Kecamatan Bogor Timur. Teknik multistage random sampling digunakan untuk memilih 139 responden. Pengumpulan data dilakukan dengan wawancara menggunakan kuesioner. Data dianalisis menggunakan uji regresi logistik ganda.

Hasil. Nilai rerata literasi kesehatan mental sebesar 73,08 (skala 100). Sebanyak 56,1\% ODMK telah memanfaatkan pelayanan kesehatan jiwa dan 57,6\% responden berumur $\geq 30$ tahun. Pada mereka yang mempunyai literasi kesehatan mental tinggi, sebanyak 64,9\% telah memanfaatkan pelayanan kesehatan jiwa. Hasil analisis multivariat menunjukkan hubungan signifikan antara literasi kesehatan mental dengan perilaku pemanfaatan pelayanan kesehatan jiwa pada ODMK setelah variabel jenis kelamin dan ketersediaan pelayanan kesehatan jiwa dikendalikan.

Kesimpulan. Orang dengan literasi kesehatan mental yang tinggi cenderung memanfaatkan pelayanan kesehatan jiwa dibanding dengan mereka dengan literasi rendah.

Kata Kunci: literasi kesehatan, kesehatan mental, pemanfaatan pelayanan kesehatan.

\begin{abstract}
Background. In Indonesia, prevalence of emotional mental disorder has increased from $6 \%$ in 2013 to $9.8 \%$ in 2018. Mental health service has not optimally utilized by people with mental health problems in East Bogor sub-district.

Objective. This study aimed to determine the relationship of mental health literacy with mental health service use.

Method. This study used a cross sectional design with a quantitative approach. Respondents were people with mental health problems who lived in East Bogor Sub-District. A total of 139 respondents were selected using multistage random sampling technique. Data were collected by in-person interview using a questionnaire. Data were analysed using a multiple logistic regression test for multivariate model selection.

Results. The results of this study showed that the mean score of mental health literacy was 73.08 (scale of 100). There were $56.1 \%$ respondents utilized mental health services. As many as $57.6 \%$ respondents aged $\geq 30$ years. Among those who have high mental health literacy, 64.9\% of them have utilized mental health services. Results from multivariate analysis showed that there was a significant relationship between mental health literacy and the use of mental health service in people with mental health problems, after adjustment with gender and mental health service availability.

Conclusion. People with high mental health literacy tended to use mental health services compared to those with low literacy.
\end{abstract}

Keywords: Health literacy, mental health, utilization of health services. 


\section{LATAR BELAKANG}

Gangguan mental merupakan salah satu tantangan kesehatan global yang memiliki dampak signifikan dikarenakan prevalensi yang tinggi dan penderitaan berat yang ditanggung oleh individu, keluarga, komunitas, dan negara. ${ }^{1}$ Gangguan mental menyumbang $16 \%$ dari beban penyakit global dan cedera pada orang yang berusia 10-19 tahun. Jumlah yang signifikan dari beban penyakit global juga ditunjukkan melalui penyakit mental. ${ }^{2}$ Berdasarkan laporan World Health Organization (WHO) tahun 2007, sebanyak 20\% orang mengalami gangguan jiwa ringan sampai sedang (depresi dan gangguan kecemasan) dan gangguan jiwa berat (depresi berat, gangguan psikotik) sebesar 3-4\%. Mereka memerlukan penanganan kesehatan jiwa yang dapat diakses melalui pelayanan kesehatan umum dan pelayanan kesehatan jiwa komunitas. ${ }^{3}$

Berdasarkan hasil Riset Kesehatan Dasar (Riskesdas) prevalensi penduduk Indonesia yang menderita gangguan mental emosional mengalami peningkatan pada tahun 2013 sebesar $6 \%$ menjadi $9,8 \%$ tahun $2018 .{ }^{4}$ Prevalensi tertinggi ada pada kelompok usia lebih dari 75 tahun dibandingkan kelompok usia lainnya, kelompok perempuan daripada lakilaki, dan kelompok yang tidak sekolah. Jawa Barat adalah provinsi ketujuh terbanyak yang memiliki prevalensi penderita gangguan mental emosional yaitu $12,1 \%$ dari populasi. ${ }^{4}$

Menurut data Dinas Kesehatan Kota Bogor jumlah orang dengan masalah kejiwaan (ODMK) di Kota Bogor terus meningkat. Jumlah ODMK di wilayah Kecamatan Bogor Timur tercatat ada 86 orang..$^{5}$ Jumlah ini kemungkinan lebih rendah daripada yang sesungguhnya. Masalah kejiwaan merupakan masalah yang masih sensitif di kalangan masyarakat. Banyak masyarakat yang tidak mengetahui masalah kejiwaan dan tidak merasakan bahwa masalah kejiwaan itu penting dan membutuhkan pertolongan.

Gangguan emosional merupakan salah satu masalah kejiwaan yang merupakan suatu kondisi perubahan emosi yang dapat berkembang menjadi patologis jika terus berlanjut. ${ }^{6}$ Oleh karena itu, langkah pencegahan agar kesehatan mental masyarakat tetap terjaga perlu dilakukan. Langkah yang bisa dilakukan yaitu dengan memberikan pendekatan terkait kesehatan mental dengan literasi kesehatan mental. $^{7}$

Sebuah studi komunitas pengungsi yang berasal dari Asia Tenggara di Amerika Serikat telah menemukan bahwa rendahnya pengguna layanan kesehatan terjadi karena kurangnya literasi kesehatan mental. Banyak orang yang tidak memiliki pengetahuan terkait apa yang dimaksud dengan penyakit mental, bagaimana mengenali tanda-tanda awalnya, perawatan apa yang tersedia, dan bagaimana serta kapan memerlukan bantuan profesional. ${ }^{8}$ Konsekuensi utama dari literasi kesehatan mental rendah yaitu keterlambatan dalam mencari bantuan, dan hasilnya adalah pengobatan yang tertunda. ${ }^{7}$

Meningkatkan literasi kesehatan mental adalah penting dan sesuai dengan rencana WHO. Kesehatan mental merupakan komponen esensial dari ikatan sosial, produktivitas, kedamaian dan stabilitas lingkungan, yang dapat berkontribusi pada perkembangan sosial dan ekonomi di masyarakat.

WHO menetapkan promosi kesehatan mental sebagai prioritas kesehatan publik. $^{9}$ Tujuannya adalah agar masyarakat yang memiliki gangguan mental segera mengambil tindakan untuk mencari bantuan professional. Mereka akan memperoleh penanganan yang berdasarkan evidence-based yang tepat, dan penderita juga akan mendapatkan dukungan dari keluarga dan dari lingkungan sekitar. Masyarakat melakukan upaya pencegahan bagi kepentingan diri sendiri maupun keluarganya, dan layanan kesehatan mental berkontribusi dalam memberikan manfaat pada masyarakat. ${ }^{10}$

Keberadaan pelayanan kesehatan jiwa sangat diperlukan untuk meningkatkan pengendalian penyakit gangguan jiwa yang prevalensinya semakin meningkat. Namun individu yang mendapatkan penanganan profesional kurang dari $10 \%$ terutama di negara-negara dengan pendapatan menengah ke bawah. ${ }^{11}$ Hal ini berakibat pada parahnya tingkat gangguan yang dialami. Selain itu, kegagalan masyarakat dalam memahami terminologi gangguan psikologis, dapat memicu munculnya stigma negatif di masyarakat mengenai 
gangguan mental sehingga enggan bagi mereka untuk mencari bantuan professional. ${ }^{12}$

Berdasarkan karakteristik individu literasi kesehatan mental rendah ditunjukkan dengan ketidakmampuan dalam identifikasi gangguan mental telah terbukti dapat mempengaruhi pencarian pertolongan formal atau pemanfaatan pelayanan kesehatan terkait gangguan mental. ${ }^{13}$ Hal tersebut adalah konsep keliru mengenai gangguan mental yang memicu orang cenderung mencari pertolongan informal. $^{14}$

Literasi kesehatan mental didefinisikan sebagai pengetahuan dan keyakinan mengenai gangguan-gangguan mental yang membantu rekognisi, manajemen, dan prevensi. ${ }^{12}$ Aspekaspek literasi kesehatan mental yaitu : (a) pengetahuan tentang bagaimana mencegah gangguan mental, (b) pengakuan kapan suatu gangguan berkembang, (c) pengetahuan tentang opsi pencarian pertolongan dan perawatan yang tersedia, (d) pengetahuan tentang strategi pertolongan mandiri yang efektif untuk masalah yang lebih ringan, dan (e) keterampilan pertolongan pertama untuk mendukung orang lain yang mengalami gangguan mental atau berada dalam krisis kesehatan mental. ${ }^{15}$

Berdasarkan penjelasan sebelumnya, masyarakat perlu diberikan informasi dan pengetahuan yang tepat mengenai gangguan psikologis. Masyarakat akan mampu mengetahui dan mengenali gejala gangguan yang ada. Selain itu, masyarakat akan mengetahui langkah yang dapat dilakukan untuk mendapatkan penanganan sedini mungkin serta dapat memanfaatkan fasilitas pelayanan kesehatan yang ada. Dalam penelitian sebelumnya literasi kesehatan mental telah diidentifikasi sebagai penghalang utama dalam mencari pertolongan pelayanan kesehatan. Penelitian ini bertujuan untuk mengetahui bagaimana literasi kesehatan mental orang dewasa dan bagaimana hubungannya dengan pemanfaatan pelayanan kesehatan setelah variabel confounding dikendalikan.

\section{METODE}

Penelitian menggunakan desain potong lintang (cross sectional). Variabel terikat adalah pemanfaatan pelayanan kesehatan jiwa, variabel bebas adalah literasi kesehatan mental, dan variabel penganggu adalah umur, jenis kelamin, pendidikan, pekerjaan, pendapatan, stigma gangguan jiwa, pelayanan petugas kesehatan dan ketersediaan pelayanan kesehatan jiwa.

Penelitian dilakukan di Kecamatan Bogor Timur, Kota Bogor pada bulan Mei 2019. Populasi penelitian ini adalah rumah tangga di wilayah Kecamatan Bogor Timur. Sampel dalam penelitian ini adalah anggota rumah tangga dengan gangguan mental emosional di wilayah Kecamatan Bogor Timur Kota Bogor Tahun 2019. Teknik pengambilan sampel penelitian dilakukan secara gugus bertahap atau multistage random sampling. Pada teknik sampel ini dilakukan berdasarkan tingkat wilayah secara bertahap.

Besar sampel minimal sebesar 136 orang dihitung menggunakan rumus sample size uji hipotesis beda dua proporsi dua sisi (two tailed). ${ }^{16}$ Penelitian ini menggunakan data berjenis data primer. Semua data penelitian dikumpulkan melalui kuesioner yang berisikan daftar pertanyaan yang mengacu pada tujuan penelitian. Sampel dalam penelitian ini adalah anggota rumah tangga yang telah dilakukan skrining gangguan mental emosional dan diindikasikan mengalami gangguan mental emosional jika menjawab $\geq 6$ pertanyaan dengan jawaban "ya" dari 20 pertanyaan yang diajukan. Pengukuran gangguan mental emosional menggunakan instrumen pskiatrik SRQ yang diadaptasi dari WHO. ${ }^{17}$

Surat lolos kaji etik penelitian didapatkan dari Komite Etik Riset dan Pengabdian Kesehatan Masyarakat Fakultas Kesehatan Masyarakat, Universitas Indonesia, dengan nomor 348/UN2.F10/PPM.00.02/2019.

\section{HASIL}

Tabel 1 menunjukan distribusi karakteristik sosiodemografi dari responden. Sebanyak $51,1 \%$ responden berumur diatas 30 tahun, $79,9 \%$ berjenis kelamin perempuan, $43,2 \%$ mempunyai pendidikan tamat SMA, 56,8\% tidak bekerja, dan $50,4 \%$ mempunyai pendapatan di bawah UMR. 
Tabel 1. Distribusi Responden Berdasarkan Karakteristik Demografi $(n=139)$

\begin{tabular}{lrr}
\hline \multicolumn{1}{c}{ Karakteristik } & (n) & $(\mathbf{\%})$ \\
\hline Umur & & \\
< 30 tahun & 68 & 48,9 \\
> 30 tahun & 71 & 51,1 \\
Jenis kelamin & & \\
Laki-laki & 28 & 20,1 \\
Perempuan & 111 & 79,9 \\
Pendidikan & & \\
Tamat SD/sederajat & 31 & 22,3 \\
Tamat SMP/sederajat & 22 & 15,8 \\
Tamat SMA/sederajat & 60 & 43,2 \\
Tamat Diploma 1-3 & 25 & 18,0 \\
Tamat D4/Sarjana & 1 & 0,7 \\
Jenis pekerjaan & & \\
Tidak bekerja & 79 & 56,8 \\
Petani & 1 & 0,7 \\
Buruh & 5 & 3,6 \\
PNS & 4 & 2,9 \\
Karyawan swasta & 43 & 30,9 \\
Wiraswasta & 7 & 5,0 \\
Pendapatan & & \\
<UMR (Rp 3.842.785) & 70 & 50,4 \\
>UMR (Rp 3.842.785) & 69 & 49,6 \\
\hline
\end{tabular}

Tabel 2 menjelaskan bahwa dari 139 responden yang terindikasi mengalami gangguan mental emosional kategori ringan, 80,6\% pernah melakukan pemeriksaan terkait keluhan mentalnya. Dari mereka yang melakukan pemeriksaan, 66,2\% melakukan pemeriksaan ke fasilitas kesehatan. Sebanyak 84,8\% dari mereka yang melakukan pemeriksaan ke fasilitas kesehatan rutin melakukan pengobatan ke fasilitas kesehatan.

Sebanyak $97,4 \%$ dari mereka yang rutin ke fasilitas kesehatan sudah berkunjung ke fasilitas kesehatan sebanyak 1-3 kali dalam 3 bulan terakhir. Sebanyak $56,4 \%$ diantaranya mengikuti sesi penyuluhan kesehatan tentang kesehatan jiwa.

Setelah dilakukan skoring atas variabel pemanfaatan pelayanan kesehatan jiwa didapat nilai rerata perilaku pemanfaatan pelayanan kesehatan jiwa sebesar 38 (skala 100). Berdasarkan hasil uji Skewness $0,063 / 0,206=-0,3(\leq 2)$, maka variabel pemanfaatan pelayanan kesehatan jiwa memiliki dis- tribusi normal sehingga dimasukan kedalam kategori dengan cut-off point yang digunakan adalah nilai mean. Sebanyak $56,1 \% \quad(\mathrm{n}=78)$ responden dikategorikan memanfaatkan pelayanan kesehatan jiwa dan 43,9\% $(n=61)$ tidak memanfaatkan pelayanan kesehatan jiwa.

Tabel 3 dan Tabel 4 menjelaskan butirbutir pertanyaan mengenai literasi kesehatan mental. Sebanyak 57,6\% responden menjawab 'sangat memungkinkan' untuk dapat mengenali ciri gangguan kecemasan. Sementara itu, sebanyak $55,4 \%$ responden menjawab 'sangat memungkinkan' bahwa jenis kelamin perempuan menjadi faktor resiko terjadinya gangguan mental.

Tabel 2. Distribusi Responden berdasarkan Pemanfaatan Pelayanan Kesehatan Jiwa

\begin{tabular}{|c|c|c|}
\hline Butir-butir pertanyaan & $\begin{array}{c}\text { Ya } \\
\mathbf{n}(\%)\end{array}$ & $\begin{array}{l}\text { Tidak } \\
\text { n }(\%)\end{array}$ \\
\hline $\begin{array}{l}\text { Melakukan pemeriksaan } \\
\text { ketika mengalami keluhan } \\
\text { terkait kesehatan mental } \\
(\mathrm{n}=139)\end{array}$ & $112(80,6)$ & $27(19,4)$ \\
\hline $\begin{array}{l}\text { Mengunjungi fasilitas } \\
\text { kesehatan }(\mathrm{n}=112)\end{array}$ & $92(66,2)$ & $20(33,8)$ \\
\hline $\begin{array}{l}\text { Melakukan pemeriksaan ru- } \\
\text { tin }(n=92) \\
\text { Jumlah kunjungan } 3 \text { bulan } \\
\text { terakhir }(n=92)\end{array}$ & $78(84,8)$ & $14(15,2)$ \\
\hline $\begin{array}{l}1-3 \text { kali } \\
>3 \text { kali }\end{array}$ & $\begin{array}{c}72(78,2) \\
6(6,5)\end{array}$ & $14(15,2)$ \\
\hline $\begin{array}{l}\text { Mengikuti kegiatan } \\
\text { penyuluhan }(n=92) \\
\text { Jumlah penyuluhan yang } \\
\text { diikuti } 3 \text { bulan terakhir } \\
(n=44)\end{array}$ & $44(56,4)$ & $48(43,5)$ \\
\hline $\begin{array}{l}1-2 \text { kali } \\
>2 \text { kali }\end{array}$ & $\begin{array}{c}43(46,7) \\
1(1,08)\end{array}$ & $48(52,1)$ \\
\hline $\begin{array}{l}\text { Melakukan konsultasi } \\
\text { dengan dokter/psikolog } \\
(\mathrm{n}=78) \\
\text { Jumlah konsultasi dengan } \\
\text { dokter/psikolog dalam } 3 \text { bu- } \\
\text { lan terakhir }(\mathrm{n}=78)\end{array}$ & $75(96,1)$ & $3(3,9)$ \\
\hline $\begin{array}{l}1-3 \text { kali } \\
>3 \text { kali }\end{array}$ & $\begin{array}{c}74(94,8) \\
1(1,2)\end{array}$ & $3(3,8)$ \\
\hline
\end{tabular}


Tabel 3. Distribusi Responden Berdasarkan Persepsi Bentuk Gangguan Mental dan Persepsi Faktor Resiko Gangguan Mental oleh ODMK (n=139)

\begin{tabular}{lcccc}
\hline \multicolumn{1}{c}{ Butir-Butir Pertanyaan } & STM & TM & M & SM \\
\cline { 2 - 4 } & n $(\%)$ & n $(\%)$ & n $(\%)$ & n $(\%)$ \\
\hline Ciri fobia sosial & $9(6,5)$ & $9(6,5)$ & $51(36,7)$ & $70(50,4)$ \\
Ciri gangguan kecemasan & $8(5,8)$ & $3(2,2)$ & $48(34,5)$ & $80(57,6)$ \\
Ciri agoraphobia & $7(5,0)$ & $11(7,9)$ & $73(52,5)$ & $48(34,5)$ \\
Ciri gangguan bipolar & $9(6,5)$ & $15(10,8)$ & $50(36,0)$ & $65(46,8)$ \\
Ketergantungan obat & $4(2,9)$ & $7(5,0)$ & $60(43,2)$ & $68(48,9)$ \\
Faktor resiko: gender perempuan & $3(2,2)$ & $10(7,2)$ & $49(35,3)$ & $77(55,4)$ \\
Tenaga kesehatan boleh melanggar & $7(5,0)$ & $13(9,4)$ & $69(49,6)$ & $50(36,0)$ \\
prinsip kerahasiaan & & & &
\end{tabular}

Keterangan: $\mathrm{STM}=$ sangat tidak mungkin, $\mathrm{TM}=$ tidak mungkin,

$\mathrm{M}=$ mungkin, $\mathrm{SM}=$ sangat memungkinkan

Tabel 4. Distribusi Responden Berdasarkan Persepsi Pencarian Informasi dan Sikap Yang Meningkatkan Pengetahuan oleh ODMK $(n=139)$

\begin{tabular}{lccccc}
\hline \multicolumn{1}{c}{ Butir-Butir Pertanyaan } & STS & TS & R & S & SS \\
\cline { 2 - 5 } & $\mathbf{n}(\%)$ & $\mathbf{n}(\%)$ & $\mathbf{n}(\%)$ & $\mathbf{n}(\%)$ & n (\%) \\
\hline Tahu cara mencari informasi & $4(2,9)$ & $15(10,8)$ & $9(6,5)$ & $61(43,9)$ & $50(36,0)$ \\
$\begin{array}{l}\text { Berani bertemu petugas kesehatan } \\
\text { Punya akses untuk mencari infor- }\end{array}$ & $15(10,8)$ & $7(5,0)$ & $63(45,3)$ & $54(38,8)$ & - \\
$\begin{array}{l}\text { masi } \\
\text { Gangguan mental merupakan tanda }\end{array}$ & $3(2,7)$ & $6(4,3)$ & $6(4,3)$ & $61(43,9)$ & $65(46,8)$ \\
$\begin{array}{l}\text { orang yang lemah } \\
\text { Gangguan mental bukan penyakit }\end{array}$ & $6(4,3)$ & $35(25,2)$ & $17(12,2)$ & $41(29,5)$ & $40(28,8)$ \\
$\begin{array}{l}\text { medis } \\
\text { Jika menderita gangguan mental } \\
\text { tidak akan memberi tahu siapapun }\end{array}$ & $20(14,4)$ & $53(38,1)$ & $11(7,9)$ & $25(18,0)$ & $30(21,6)$ \\
\hline
\end{tabular}

Keterangan: $\mathrm{STS}=$ sangat tidak setuju, $\mathrm{TS}=$ tidak setuju, $\mathrm{R}=$ ragu-ragu, $\mathrm{S}=$ setuju, $\mathrm{SS}=$ sangat setuju

Tabel 5. Distribusi Responden Berdasarkan Literasi Kesehatan Mental dan Variabel Perancu $(n=139)$

\begin{tabular}{lll}
\hline \multicolumn{1}{c}{ Variabel } & n & \% \\
\hline $\begin{array}{l}\text { Literasi Kesehatan Mental } \\
\text { (rerata=73.08; min-maks= 44-93) }\end{array}$ & & \\
$\quad$ Tinggi $(>73,08)$ & 77 & 55,4 \\
$\quad$ Rendah $(\leq 73,08)$ & 62 & 44,6 \\
$\begin{array}{l}\text { Stigma gangguan jiwa } \\
\text { (rerata=67,27; min-maks= 55-87) }\end{array}$ & & \\
$\quad$ Tinggi $(>67,27)$ & 66 & 47,5 \\
$\quad$ Rendah $(\leq 67,27)$ & 73 & 52,5 \\
$\begin{array}{l}\text { Pelayanan petugas kesehatan } \\
\text { (rerata=63,87; min-maks= 33-100) }\end{array}$ & & \\
$\quad$ Baik $(>63,87)$ & 76 & 54,7 \\
$\quad$ Kurang $((\leq 63,87)$ & 63 & 45,3 \\
$\begin{array}{l}\text { Ketersediaan layanan kesehatan jiwa } \\
\text { (rerata=54,8; min-maks=0-100) }\end{array} \quad$ & \\
$\quad$ Tersedia & & \\
$\quad$ Tidak tersedia & 92 & 66,2 \\
\hline
\end{tabular}

Tabel 6. Distribusi Responden Berdasarkan Literasi Kesehatan Mental dan Perilaku Pemanfaatan Pelayanan Kesehatan Jiwa $(\mathbf{n}=\mathbf{1 3 9})$

\begin{tabular}{|c|c|c|c|c|c|c|c|}
\hline \multirow{3}{*}{ Literasi kesehatan mental } & \multicolumn{4}{|c|}{ Pemanfaatan Pelayanan Kesehatan Jiwa } & \multirow{2}{*}{\multicolumn{2}{|c|}{ Total }} & \multirow[b]{3}{*}{ p-value } \\
\hline & \multicolumn{2}{|c|}{ Memanfaatkan } & \multicolumn{2}{|c|}{ Tidak Memanfaatkan } & & & \\
\hline & $\mathbf{n}$ & $\%$ & $\mathbf{n}$ & $\%$ & $\mathbf{n}$ & $\%$ & \\
\hline Tinggi & 50 & 64,9 & 27 & 35,1 & 77 & 100 & 0,031 \\
\hline Rendah & 28 & 45,2 & 34 & 54,8 & 62 & 100 & \\
\hline
\end{tabular}


Tabel 7. Pemodelan Uji Multivariat

\begin{tabular}{lccccc}
\hline & \multicolumn{6}{c}{ Pemodelan Ke- . . } \\
\cline { 2 - 6 } \multicolumn{1}{c}{ Variabel } & $\mathbf{1}$ & $\mathbf{2}$ & $\mathbf{3}$ & $\mathbf{4}$ & $\mathbf{5}$ \\
\cline { 2 - 6 } & 0,003 & 0,001 & 0,004 & 0,014 & 0,018 \\
\hline $\begin{array}{l}\text { Variabel independen } \\
\quad \text { Literasi kesehatan mental } \\
\text { Variabel perancu } \\
\quad \text { Jenis kelamin }\end{array}$ & 0,421 & 0,403 & $-*$ & - & - \\
$\quad$ Pekerjaan & 0,005 & 0,004 & 0,004 & 0,005 & - \\
$\quad$ Stigma gangguan jiwa & 0,030 & 0,026 & 0,027 & $-*$ & - \\
$\quad$ Ketersediaan & 0,152 & $-*$ & 0,147 & 0,126 & 0,085 \\
OR Literasi kesehatan mental & 3,653 & 4,524 & 3,572 & 2,734 & 2,521 \\
Perubahan OR & \multicolumn{7}{c}{$23,8 \%$} & $-2,2 \%$ & $-25 \%$ & $-30 \%$ \\
\hline Keterangan: * = variabel yang dikeluarkan dari pemodelan &
\end{tabular}

Tabel 4 menjelaskan bahwa 46,8\% responden mengatakan mempunyai akses untuk mencari informasi terkait kesehatan mental. Sebanyak 45,3\% responden merasa ragu-ragu bertemu dengan petugas kesehatan.

Tabel 5 menjelaskan bahwa nilai rerata literasi kesehatan mental responden sebesar 73,08 (skala 100). Nilai rerata stigma tentang gangguan jiwa sebesar 67,27 (skala 100). Nilai rerata pelayanan petugas kesehatan adalah 63,87 (skala 100). Nilai rerata ketersediaan pelayanan kesehatan sebesar 54,8 (skala 100).

Tabel 6 menjelaskan responden yang memanfaatkan pelayanan kesehatan jiwa, 64,9\% memiliki literasi kesehatan mental yang tinggi dibanding dengan 45,2\% yang memiliki literasi rendah. Hasil uji chi square nilai $\mathrm{p}=0,031$ maka dapat disimpulkan ada hubungan yang signifikan antara literasi kesehatan mental dengan perilaku pemanfaatan pelayanan kesehatan jiwa.

Hasil uji bivariat digunakan untuk menyeleksi variabel yang akan digunakan pada tahap uji multivariat. Variabel yang dapat masuk ke tahap multivariat jika memiliki nilai $\mathrm{p}<0,25$. Variabel jenis kelamin, pekerjaan, stigma gangguan jiwa dan ketersediaan pelayanan kesehatan jiwa memiliki nilai $\mathrm{p}<0,25$ sehingga variabel tersebut masuk kedalam tahap uji multivariat

Tabel 7 menjelaskan bahwa berdasarkan hasil pemodelan terakhir, didapatkan bahwa variabel ketersediaan pelayanan kesehatan jiwa merupakan variabel perancu hubungan dari literasi kesehatan mental dengan perilaku pemanfaatan pelayanan kesehatan jiwa. Berdasarkan pemodelan multivariat dapat dijelaskan bahwa masyarakat dengan gangguan mental emosional yang mempunyai literasi kesehatan mental tinggi mempunyai peluang memanfaatkan pelayanan kesehatan jiwa dua kali dibandingkan dengan masyarakat yang mengalami gangguan mental dan mempunyai literasi kesehatan mental rendah, setelah variabel ketersediaan pelayanan kesehatan jiwa dikendalikan.

Responden dalam penelitian ini adalah anggota rumah tangga yang telah dilakukan skrining gangguan mental emosional, yang menunjukkan indikasi mengalami gangguan mental emosional setelah menjawab $\geq 6$ pertanyaan dengan jawaban "ya" dari sebanyak 20 pertanyaan yang diajukan.

\section{PEMBAHASAN}

Responden dengan gangguan mental emosional yang melakukan pemeriksaan khusus pada saat mengalami gejala-gejala seperti yang disebutkan dalam SRQ dalam 1 bulan terakhir sebanyak 112 orang $(80,6 \%)$. Tempat yang dikunjungi untuk melakukan pemeriksaan adalah $62,2 \%$ ke fasilitas kesehatan dan $33,8 \%$ pergi ke fasilitas non kesehatan yaitu pengobatan tradisional. Masyarakat masih memanfaatkan pengobatan tradisional untuk mengobati masalah gangguan mental dikarenakan karena di Indonesia pengobatan tradisional merupakan cara yang mudah, terjangkau dan tersedia bagi penduduk Indonesia yang menderita gangguan jiwa. ${ }^{4}$ Kebanyakan dari mereka yang merasa keluhan-keluhan mengarah ke gangguan mental lebih memilih metode penyembuh tradisional dan alternatif terlebih dahulu sebelum pergi ke fasilitas kesehatan. ${ }^{18}$ 
Pada responden yang tidak rutin ataupun tidak memanfaatkan pelayanan kesehatan menurut Twoddle dalam Notoatmodjo. ${ }^{19} \mathrm{Hal}$ ini disebabkan karena apa yang dirasakan sehat bagi seseorang bisa saja tidak dirasakan sehat bagi orang lain sehingga terjadi perbedaan persepsi konsep sehat dan sakit. Selain itu, bagi masyarakat yang mendapatkan masalah kesehatan namun tidak merasakan sakit sudah barang tentu tidak akan bertindak apaapa terhadap penyakit tersebut dan mereka menganggap bahwa kondisi demikian tidak akan mengganggu kegiatan atau kerja mereka sehari-hari atau mungkin mereka beranggapan bahwa tanpa bertindak apa pun gejala yang dideritanya akan lenyap dengan sendirinya. ${ }^{19}$

Tingkat literasi kesehatan mental dalam penelitian ini sebagian besar tergolong baik. Nilai rerata literasi kesehatan mental dari masyarakat di Kecamatan Bogor Timur Kota Bogor sebesar 73,08, dengan nilai terrendah adalah 44 dan nilai tertinggi adalah 93 .

Sebagian besar responden mampu mengenali gejala-gejala gangguan mental. Hal ini berarti bahwa pengetahuan responden mengenai gejala gangguan mental cukup baik sehingga berbekal dengan pengetahuan tersebut akan mendorong seseorang dalam mencari pertolongan dari tenaga formal dibandingkan informal. $^{20}$ Selain gejala gangguan mental, sebanyak $55,4 \%$ responden pun mengetahui mengenai faktor resiko terjadinya gangguan mental disebabkan oleh faktor gender.

Sebagian masyarakat dengan gangguan mental emosional melakukan pemeriksaan khusus pada saat mereka mengalami gejalagejala gangguan. Tempat yang dikunjungi untuk pemeriksaan kesehatan umumnya adalah ke fasilitas kesehatan.

Sebagian kecil masyarakat yang masih memanfaatkan pengobatan tradisional untuk mengobati masalah gangguan mental. Pengobatan tradisional merupakan cara yang mudah, terjangkau dan tersedia bagi penduduk Indonesia yang menderita gangguan jiwa. Kebanyakan dari mereka yang merasa keluhan-keluhan yang mengarah ke gangguan mental lebih memilih metode penyembuh tradisional dan alternatif terlebih dahulu sebelum pergi ke fasilitas kesehatan. ${ }^{18}$
Pada mereka yang mendatangi fasilitas kesehatan untuk memeriksakan masalah kesehatan mentalnya, sebagian besar yang berobat secara rutin. Menurut Notoatmodjo ${ }^{19}$ hal ini menunjukkan bahwa masyarakat dengan persepsi sehat-sakit yang sebenarnya dapat merasakan risiko pribadi atau kerentanan. Persepsi kerentanan merupakan salah satu persepsi yang lebih kuat dalam mendorong orang untuk mengadopsi perilaku sehat. Semakin besar risiko yang dirasakan, semakin besar kemungkinan terlibat dalam perilaku untuk mengurangi risiko.

Untuk mengurangi risiko kesehatan tersebut, masyarakat memanfaatkan pelayanan kesehatan yang dianggap sebagai pemberi pelayanan kesehatan yang dipercaya mampu mengatasi masalah kesehatan yang mereka alami. Hawari ${ }^{18}$ menyatakan kebanyakan dari mereka yang merasa keluhan-keluhan yang mengarah ke gangguan mental lebih memilih metode penyembuh tradisional dan alternatif terlebih dahulu sebelum pergi ke fasilitas kesehatan.

Sebagian besar dari responden mampu mengenali gejala-gejala gangguan mental. Hal ini berarti bahwa pengetahuan responden mengenai gejala gangguan mental sudah baik. Pengetahuan yang baik akan mendorong seseorang dalam mencari pertolongan tenaga formal dibandingkan informal. ${ }^{20}$ Selain gejala gangguan mental, sebanyak $55,4 \%$ responden pun mengetahui mengenai faktor resiko terjadinya gangguan mental disebabkan oleh faktor gender.

Sebagian besar responden sudah mengetahui bagaimana mencari informasi tentang kesehatan mental. Dewasa ini informasi tersebar luas melalui media baik media elektronik, media cetak maupun media sosial yang kini tidak lepas dari pandangan masyarakat Indonesia. Berdasarkan survei dari Global Web Index pada kuartal II dan kuartal III tahun 2018, pengguna media sosial di Indonesia paling aktif berada di usia 16-64 tahun. Survei ini juga menunjukkan aktivitas masyarakat Indonesia mengunjungi media sosial dengan rerata waktu yang dihabiskan per hari yakni 3 jam 26 menit. Dimana diantara rentang waktu tersebut, masyarakat mendapatkan informasi mengenai kesehatan mental. ${ }^{22}$ 
Penelitian ini menemukan ada hubungan signifikan antara literasi kesehatan mental dengan perilaku pemanfaatan pelayanan kesehatan jiwa. Dengan demikian, hipotesis alternatif penelitian diterima. Responden yang mempunyai literasi kesehatan mental tinggi akan cenderung untuk memanfaatkan pelayanan kesehatan jiwa dibandingkan dengan responden yang mempunyai literasi kesehatan rendah. Hasil ini sejalan dengan penelitian Novianty $^{23}$ yang menjelaskan bahwa literasi kesehatan mental akan dapat mempengaruhi seseorang dalam perilaku pencarian pertolongan formal. Temuan ini mengindikasikan apa yang diketahui individu dan apa yang diterima masyarakat mempengaruhi pencarian pertolongan formal. Sementara itu, penelitian yang dilakukan oleh $\mathrm{Kim}^{24}$ menunjukkan bahwa literasi kesehatan mental bersifat memediasi hubungan antara tiga faktor sosialdemografis (pendidikan, literasi umum, dan status kesehatan), dan pemanfaatan pelayanan kesehatan mental.

Hal ini serupa dengan penelitian Ziller ${ }^{25}$ yang menyatakan bahwa pelayanan kesehatan yang berasal dari fasilitas kesehatan dasar lebih banyak dimanfaatkan oleh masyarakat dibandingkan pelayanan kesehatan khusus karena pelayanan dari fasilitas kesehatan dasar lebih menerima pelayanan psikoterapi yang mudah dilakukan bagi masyarakat. Selain itu psikoterapi juga merupakan komponen yang penting dari perawatan kesehatan mental yang baik.

Dewasa ini literasi kesehatan menjadi bagian yang sangat penting dalam konteks pembangunan kesehatan. Menurut Zarcadoolas ${ }^{26}$, rendahnya tingkat literasi kesehatan dapat berkontribusi terhadap beberapa masalah kesehatan, seperti penggunaan obat-obatan yang tidak semestinya, pelayanan kesehatan yang tidak mencukupi, manajemen yang buruk untuk kondisi kronis, tanggapan lamban untuk kondisi-kondisi yang kritis, kondisi kesehatan yang kurang baik, rendahnya keyakinan dan penghargaan diri, terkurasnya keuangan individu dan masyarakat dan diskriminasi secara sosial.

\section{KESIMPULAN}

Masyarakat yang mengalami masalah kejiwaan di Kecamatan Bogor Timur memiliki literasi kesehatan mental yang baik. Literasi kesehatan mental yang baik cenderung membuat mereka lebih memanfaatkan pelayanan kesehatan jiwa. Hubungan tersebut juga dipengaruhi ketersediaan pelayanan kesehatan.

\section{SARAN}

Perlunya peningkatan pengetahuan, sikap, keyakinan dan isu-isu kesehatan mental guna meningkatkan literasi kesehatan mental yang lebih baik lagi bagi masyarakat yang berisiko seperti ODMK. Selain itu, perlunya peningkatan informasi mengenai keberadaan layanan kesehatan jiwa yang ada baik puskesmas maupun rumah sakit. Sehingga mereka lebih dapat memanfaatkan layanan kesehatan jiwa yang tersedia.

\section{UCAPAN TERIMA KASIH}

Penulis mengucapkan terima kasih kepada seluruh responden yang telah bersedia berpartisipasi dalam penelitian ini.

\section{DAFTAR REFERENSI}

1. Kohn R, Saxena S, Levav I, Saraceno B. The treatment gap in mental health care. 2004; (December).

2. Whiteford et al. Global Burden of Mental, Neurological, and Substance Use Disorders: An Analysis from the Global Burden of Disease Study 2010. Dis Control Priorities, Third Ed (Volume 4) Ment Neurol Subst Use Disord [Internet]. 2016;29-40. Available from: http://elibrary.worldbank.org/doi/10.1596/97 8-1-4648-0426-7_ch2

3. Kaplan. Study Guide And Self-Examination Review In Psychiatry. Lippincot Williams, editor. 2007.

4. Kemenkes RI. Potret Sehat Indonesia dari Riskesdas 2018 [Internet]. 2018. Available from:

http://www.depkes.go.id/article/view/181102 00003/potret-sehat-indonesia-dari-riskesdas2018.html

5. Dinas Kesehatan Kota Bogor. Profil Kesehatan Kota Bogor tahun 2017. Kota Bogor: Dinkes Kota Bogor; 2018.

6. Surjaningrum ER. Gambaran Mental Health Literacy Kader Kesehatan. 2012;14(03):194- 
202.

7. Kelly CM, Jorm AF, Wright A. Improving mental health literacy as a strategy to facilitate early intervention for mental disorders. Med J Aust. 2007;187(7 Suppl):15.

8. Lee HY, Kathy $\mathrm{L}, \mathrm{Pa} \mathrm{N}$ yang, Terry $\mathrm{L}$. Mental Health Literacy in Hmong and Cambodian Elderly Refugees: A Barrier to Understanding, Recognizing, and Responding to Depression. 2010; Vol 71(Issue 4).

9. Campos et al. Is It Possible to "Find Space for Mental Health" in Young People? Effectiveness of a School-Based Mental Health Literacy Promotion Program. Int J Environ Res Public Health [Internet]. 2018;15(7):1426. Available from: http://www.mdpi.com/1660-4601/15/7/1426

10. Jorm AF. Mental health literacy; empowering the community to take action for better mental health. Am Psychol. 2011;67(3):23143.

11. Vogel et al. Measuring the self-stigma associated with seeking psychological help. J Couns Psychol. 2006;53(3):325-37.

12. Jorm AF. Mental Health Literacy: Public Knowledge and beliefs about mental disorders. Br J psychiatry. 2000;396-401.

13. Andersson et al. Help-seeking behaviour, barriers to care and experiences of care among persons with depression in Eastern Cape, South Africa. J Affect Disord [Internet]. 2013;151(2):439-48. Available from: http://dx.doi.org/10.1016/j.jad.2013.06.022

14. Umubyeyi et al. Help-seeking behaviours, barriers to care and self-efficacy for seeking mental health care: a population-based study in Rwanda. Soc Psychiatry Psychiatr Epidemiol. 2016;51(1):81-92.

15. Kutcher S, Wei Y, Coniglio C. Mental health literacy: Past, present, and future. Can J Psychiatry. 2016;61(3):154-8.

16. Lemoshow, Stanley. Adequacy of Sample Size in Health Studies. Canada: John Willey \& Sons; 1990.

17. M. Beusenberg And J.Orley. A User's Guide To The Self Reporting Questionnaire (SRQ). Geneva: WHO; 1994.

18. Hawari D. Manajemen Stres, Cemas, dan Depresi. Jakarta: Fakultas Kedokteran Universitas Indonesia; 2001.

19. Notoatmodjo S. Promosi Kesehatan dan Ilmu Perilaku. Jakarta: Rineka Cipta; 2014.

20. Kutcher et al. Mental health literacy: Past, present, and future. Can $\mathrm{J}$ Psychiatry. 2016;61(3):154-8.

21. Notoatmodjo S. Promosi kesehatan dan ilmu perilaku. Rineka Cipta Jakarta. 2007;

22. Hariyanti NT, Wirapraja A. Pengaruh Influencer MARKETING Sebagai Strategi Pemasaran Digital Era Moderen (Sebuah Studi Literatur). 2018;15(1):133-46.

23. Novianty A, Rochman Hadjam MN. Literasi Kesehatan Mental dan Sikap Komunitas sebagai Prediktor Pencarian Pertolongan Formal. J Psikol [Internet]. 2017;44(1):50. Available from: https://jurnal.ugm.ac.id/jpsi/article/view/2298 8

24. Kim et al. Mental health literacy as a mediator in use of mental health services among older Korean adults. Int Psychogeriatrics. 2017;29(2):269-79.

25. Ziller EC, Anderson NJ, Coburn AF. Access to Rural Mental Health Services: Service Use and Out-of-Pocket Costs. J Rural Heal. 2010;26(3):214-24.

26. Zarcadoolas C, Pleasant A, Greer DS. Understanding health literacy: An expanded model Understanding health literacy: an expanded model SUMMARY. 2005;(July). 